\title{
Advancing Primocane-fruiting Raspberry Production in the Intermountain West Using Spring Protection
}

Brent L. Black ${ }^{1,4}$, Tiffany Maughan ${ }^{2}$, Christina Nolasco ${ }^{3}$, and Blake Christensen ${ }^{3}$

Plants, Soils and Climate Department, Utah State University, Logan, UT 84322-4820

Additional index words. Rubus, high tunnel

\begin{abstract}
Winter injury to raspberry floricanes commonly limits productivity in cold climates. Primocane-fruiting raspberries avoid winter injury by fruiting on first year canes, but fruit production in the high-elevation valleys of the Intermountain West is later than needed for local markets, and may be limited by early fall freezes. High tunnels were used for early spring heat to advance primocane growth and the fruiting season of two primocane-fruiting red raspberry cultivars. Tunnels were covered with plastic in March and April. Then, they were covered with shade cloth during fruit ripening. Tunnel-covered plots were compared with field plantings for primocane growth rate, fruiting season, yield, and fruit quality over two seasons. High tunnels increased cane growth rate, with the harvest season advanced by 18 to 26 days depending on season and cultivar, but they did not consistently affect the total season yield or fruit size. Low-cost two-season tunnels used in conjunction with early-season primocane-fruiting raspberries may provide a viable method for small acreage producers in harsh climates to reliably supply high-value seasonal raspberry markets.
\end{abstract}

Raspberries are an important fruit crop in the Intermountain West, particularly for smallacreage farms. Many high-elevation (>1300 m) areas in the region are faced with challenging growing conditions including cold winter temperatures and relatively short growing seasons. Producers in these areas have historically grown floricane-fruiting cultivars with some winter cold hardiness (Barlow, 1963; Black et al., 2015). However, yields are often limited by severe winter dieback of floricanes or flower damage due to late spring freezes.

Canes of primocane-fruiting (PF) cultivars can be cut to the ground each year to focus on a fall crop only, or they can be double-cropped, producing a fall crop on the upper portion of the primocane, with the rest of the cane producing a summer (floricane) crop the following season. Focusing only on the fall crop provides labor savings through sim-

Received for publication 3 Dec. 2018. Accepted for publication 17 Dec. 2018

We gratefully acknowledge the technical assistance of James Frisby.

Funding was provided by grants from Utah State University Extension and the Utah Agricultural Experiment Station-Utah State University (journal paper UAES \#9151).

Use of trade names does not imply an endorsement of the products named or criticism of similar ones not named.

${ }^{1}$ Professor.

${ }^{2}$ Research Associate.

${ }^{3}$ Undergraduate Extension Intern.

${ }^{4}$ Corresponding author. E-mail: brent.black@usu. edu. plified pruning. A fall-only cropping system also eliminates the risk of reduced yields caused by severe winter or late spring weather conditions. For many PF raspberry cultivars, however, fruiting begins late during the season, and production is often shortened by fall freeze events before yields can reach commercially viable levels (Nonnecke and Luby, 1992; Privé et al., 1993a). This is particularly common in the high-elevation mountain valleys of the Intermountain West (Black et al., 2013).

Season extension methods may allow for commercially viable yields of PF raspberries in climates found in the Intermountain West. High tunnels covered during the fall extend the production season beyond the first fall freezes and have been successfully used in New York (Pritts, 2006), Pennsylvania (Demchak et al., 2003), and Minnesota (Yao and Rosen, 2011). However, extension of the late fall season has had less consistent results in Northern Utah (Maughan and Black, 2018; Rowley, 2010), depending on the timing and severity of the fall freezes. Weber (2018) reported that fall-bearing raspberries grown under high tunnels reached full yield potential over a 10 -week harvest season in New York; however, the beginning and end of the fruit harvest in the tunnels were not compared with those of field production.

Season extension methods may also be used to advance cane growth to move the production season earlier. Raspberry growth rate increases with temperature up to $22{ }^{\circ} \mathrm{C}$ (Carew et al., 2003). Pritts et al. (1992) accelerated primocane growth by using row covers over the raspberry beds from late winter until primocanes were $\approx 0.5 \mathrm{~m}$ tall.
This resulted in fruit ripening occurring as much as 3 weeks earlier than that of uncovered plants, with a subsequent increase in seasonlong yields. Similarly, Strik et al. (2012) reported a 2-week advancement in the bloom of PF blackberries when covered with row covers during early spring in Oregon. Hanson et al. (2011) reported that PF raspberries grown under a three-season (April to November) high tunnel in Michigan ripened 1 week earlier, and that harvest was extended 1 week later than in the field. Demchak (2009) reported that $\mathrm{PF}$ raspberries grown under a four-season high tunnel ripened $\approx 4$ weeks earlier than what is typical of field production; however, no direct comparison with field planting was included.

Tunnel structures represent significant initial costs, and labor for maintaining the tunnels and the protected crops represents significant input. Simple tunnels that can be covered for specific short-term effects (one or two seasons) can represent significant savings in tunnel and crop management while still providing horticultural advantages. Using a one-season or two-season tunnel could provide advantages for raspberry production at a lower cost than the three-season and fourseason tunnel approaches. The objective of this research was to determine the degree to which spring-covered high tunnels would advance primocane development and fruit production in the high-elevation valleys of the Intermountain West.

\section{Materials and Methods}

Planting. A replicated planting of $\mathrm{PF}$ raspberries was established at the Utah State University Greenville Research farm in North Logan, UT (lat. $41.73^{\circ} \mathrm{N}$, long. $111.83^{\circ} \mathrm{W}, 1430 \mathrm{~m}$ elevation) in 2010 . The average freeze-free season is $135 \mathrm{~d}$, with the average first fall freeze occurring 25 Sept. (Moller and Gillies, 2008). The planting consisted of eight rows that were $12.8 \mathrm{~m}$ long. Cultivars were Caroline (Swartz et al., 1998) and Josephine (Swartz et al., 2001), which were planted in paired rows with $2.1 \mathrm{~m}$ between rows. Four of the rows were covered with two high tunnels, and four rows were left open. Each row initially consisted of $\approx 21$ plants obtained from a commercial nursery (Nourse Farms, Whately, MA) planted with in-row spacing of $0.6 \mathrm{~m}$. From 2011 to 2015 , the tunnels were covered during the fall to test late fall season extension (Maughan and Black, 2018), before transitioning to compare early season extension for the 2016 and 2017 seasons.

Cultivars. Caroline is a PF cultivar with medium-sized, good-flavored, conical fruit with good firmness, and color that ripens 7 to $10 \mathrm{~d}$ earlier than does 'Heritage' (Black et al., 2013; Handley and Weber, 2008). Pritts (2006) classified 'Caroline' as a high-quality cultivar that was limited in production in the Northeast by the first fall freeze. 'Caroline' is less susceptible to druplet syndrome bleaching from heat stress than is 'Heritage' and some other fall-bearing cultivars, has shown 
relatively low susceptibility to raspberry horntail (Hartigia cressonii; Black et al., 2013), and has good resistance to Phytophthora root rot (Handley and Weber, 2008).

Josephine is a PF cultivar with firm, darker colored berries with excellent flavor (Pritts et al., 2017) that ripens later than does Heritage (Handley and Weber, 2008). Pritts (2006) classified 'Josephine' as a late-season producer that is limited by first fall freezes in the Northeast. When trialed in a high tunnel in New York, 'Josephine' produced outstanding fruit quality.

Cultural practices. Irrigation was provided using a drip system, with a single drip tape installed in the center of each row. Irrigation started in June, with approximately two irrigation events per week based on crop need; the needs were determined by monitoring soil water potential (Watermark Soil Moisture Sensor; Irrometer, Riverside, CA). Plant nutrient needs were supplied with fertilizer applications through the irrigation system beginning in early June using combinations of urea, ammonium sulfate, and 20N-20P-20K Peter's Professional liquid fertilizer (The Scotts Co., Marysville, $\mathrm{OH})$. In 2016, the fertilizer application rates were $6.0,0.7$, and $1.0 \mathrm{~kg} \cdot \mathrm{ha}^{-1}$ per week of $\mathrm{N}$, $\mathrm{P}$, and $\mathrm{K}$, respectively. During the 2017 season, errors were made in the fertilizer injection rate, and weekly rates increased to an average of $13.3,2.4$, and $3.0 \mathrm{~kg} \cdot \mathrm{ha}^{-1}$ of $\mathrm{N}, \mathrm{P}$, and $\mathrm{K}$, respectively. A small amount of iron chelate was added to the fertilizer solution periodically to remedy chlorosis.

Canes were pruned according to typical regional practices; all canes were removed in late winter before new growth began. Canes were supported with a T-trellis system consisting of rows of twine on each side of the row at $0.6 \mathrm{~m}, 0.9 \mathrm{~m}$, and $1.5 \mathrm{~m}$ above the ground. Inrow weed control involved a combination of annual applications of preemergent herbicide (1.9-2.8 L.ha ${ }^{-1}$ Surflan; Southern Agricultural Insecticides, Palmetto, FL) and hand weeding.

Two low-cost PVC-frame high tunnels were used. One was $4.4 \mathrm{~m}$ wide $\times 3 \mathrm{~m}$ tall $\times$ $12.2 \mathrm{~m}$ long (Maughan et al., 2014). The second tunnel was $5.3 \mathrm{~m}$ wide $\times 2.7 \mathrm{~m}$ tall $\times$ $12.2 \mathrm{~m}$ long. Both were covered with 6-mil greenhouse-grade plastic on 21 Mar. 2016 and 15 Mar. 2017. Plastic was removed on 5 May 2016 and 5 June 2017. Shade cloth (30\%; FarmTek, Dyersville, IA) was installed when the first fruit began ripening (12 Aug. 2016 and 19 July 2017). In 2016, floating row cover (AG-19; $15 \mathrm{~g} \cdot \mathrm{m}^{-2}$; Agribon J\&M Industries Inc., Ponchatoula, LA) was used to cover plots inside the high tunnels. In 2017, the plots were divided; half of the plot was covered in row cover and the other half was covered with low tunnels (2-mil construction-grade plastic). There were no significant differences between the two covering types, and results were pooled. Row covers were applied to plots on 21 Mar. 2016 and 24 Mar. 2017; they were removed 7 Apr. 2016 and 25 Apr. 2017.

Data collection. Each season, 10 random canes in each plot were selected and flagged.
These marked canes were measured weekly beginning 18 May 2016 and 12 Apr. 2017. Ripe berries were harvested three times per week. Total and marketable yield per plot were recorded at each harvest. Mean fruit weight was determined at each harvest for a 10 -fruit subsample. The weighted average fruit size was calculated for the season using the subsample fruit weight and its fraction of the total seasonal yield harvested on that date. To characterize the production season, cumulative yield curves were generated and linear regression was calculated to determine the harvest start (X-axis intercept) and midpoint dates for each plot and season. These production season benchmarks were then used to compare cultivars and growing environments over the course of the two seasons.

Statistics. Yield, fruit size, harvest season, and cane height for 2 years were analyzed as two growing conditions (with or without tunnel) $\times$ two cultivars factorials with repeated measures (year) and two replicates. The GLM procedure of the SAS software package (version 9.4; SAS, Cary, NC) was used.

\section{Results and Discussion}

Spring high tunnel protection significantly advanced primocane growth over both seasons. However, the effect differed by year and cultivar, as indicated by significant tunnel $\times$ cultivar $(P=0.0003)$ and tunnel $\times$ year $(P=0.008)$ interactions (Table 1). The advancement in primocane growth was more pronounced in 'Caroline', for which canes reached the $90-\mathrm{cm}$ height benchmark 28 and $42 \mathrm{~d}$ earlier than that of the 'Caroline' field treatments in 2016 and 2017, respectively (Table 1). Regarding the later fruiting for 'Josephine', the date when the cane height reached the $90-\mathrm{cm}$ benchmark was minimally advanced in 2016, but it was advanced by $26 \mathrm{~d}$ in 2017. The $90-\mathrm{cm}$ benchmark was selected for comparison because on 18 May 2016, when the initial measurements were performed, the average cane height of the tunnel 'Caroline' treatment was $81.0 \mathrm{~cm}$; for the field treatment, it was $26.6 \mathrm{~cm}$ (data not shown). For 'Josephine', the tunnel height at the first measurement date was $49.9 \mathrm{~cm}$; however, it was $24.8 \mathrm{~cm}$ for the field planting. For both cultivars and across both seasons, the cane growth rate was significantly higher $(P=0.019)$ in the field than in the tunnels.

Advanced cane growth corresponded with an earlier fruiting season. For all treatments, small quantities of ripe fruit were harvested for several weeks before significant production began (Fig. 1). We previously noted that this early fruit is often from basal floricane buds that produce relatively long fruiting shoots from ground level (Black et al., 2013), even when the planting is pruned for a fall-only crop. Typically, these very early fruits are not of sufficient quantity to be commercially harvested. To compare the onset of the commercial harvest among treatments, the harvest start and midpoint were calculated for each plot using linear regression, as described previously.

The harvest start date was significantly affected by the tunnel treatment, but not by the cultivar (Table 2). The calculated harvest start date for 'Caroline' in tunnels was 30 July during both years compared with 25 Aug. for the field planting (a 26-d difference). The season midpoint did not show the same level of advancement, with a 21-d difference between the tunnel and field treatments for 'Caroline'. The season midpoint was also affected by year $(P=0.028)$; the midpoint was reached 2 to $4 \mathrm{~d}$ earlier in 2017 than in 2016. These benchmarks indicated that the harvest season progressed more quickly in the field than in tunnels. The tunnels were covered by $30 \%$ shade cloth before fruit harvest to reduce sunburned fruit. The shade cloth may have reduced heat accumulation enough to slow the progression of the harvest season.

The effect of the high tunnel system on marketable fruit differed somewhat by cultivar and year. In general, marketable fruit as a percentage of total yield was higher in the tunnels than in the field (Table 3), but this tunnel effect was much more pronounced in 2016 than in 2017. In general, there was a higher percentage of marketable fruit in 2016 than in 2017 across all tunnel and cultivar combinations. Fruit were deemed unmarketable for a number of reasons, including soft or malformed fruit, sunburn (bleached drupelets), and damage from insects or disease. Sunburn is typically the most prevalent cause of unmarketable fruit under conditions found in Utah (Black et al., 2013, 2015). The

Table 1. Effects of a two-season high tunnel system on primocane growth of two cultivars over two seasons. Cane growth response is compared based on the date when the mean cane height surpassed 90 $\mathrm{cm}$ and on the cane growth rate, as determined by linear regression. Values are based on measurements of 10 marked canes per plot.

\begin{tabular}{|c|c|c|c|c|c|c|c|}
\hline \multirow[b]{2}{*}{$\mathrm{Yr}$} & \multirow[b]{2}{*}{ Cultivar } & \multicolumn{3}{|c|}{$90 \mathrm{~cm} \mathrm{ht} \mathrm{(date)}$} & \multicolumn{3}{|c|}{ Cane growth rate $(\mathrm{cm} / \mathrm{d})$} \\
\hline & & Tunnel & Field & $\overline{\text { dif. }}$ & Tunnel & Field & dif. \\
\hline \multirow[t]{2}{*}{2016} & Caroline & 28 May & 25June & 28 & 1.14 & 1.68 & 0.54 \\
\hline & Josephine & 19 June & 21 June & 2 & 1.50 & 1.90 & 0.40 \\
\hline \multirow[t]{2}{*}{2017} & Caroline & 19 May & 30 June & 42 & 1.49 & 1.59 & 0.10 \\
\hline & Josephine & 6 June & 2 July & 26 & 1.31 & 1.70 & 0.40 \\
\hline \multicolumn{8}{|c|}{ Analysis of variance $P$ values } \\
\hline & Tunnel & & 0.0001 & & & 0.019 & \\
\hline & Cultivar & & 0.0003 & & & 0.19 & \\
\hline & Tunnel $\times$ cultivar & & 0.0003 & & & 0.65 & \\
\hline & Year & & 0.3 & & & 0.61 & \\
\hline & Tunnel $\times$ year & & 0.008 & & & 0.12 & \\
\hline & Cultivar $\times$ year & & 0.81 & & & 0.049 & \\
\hline
\end{tabular}



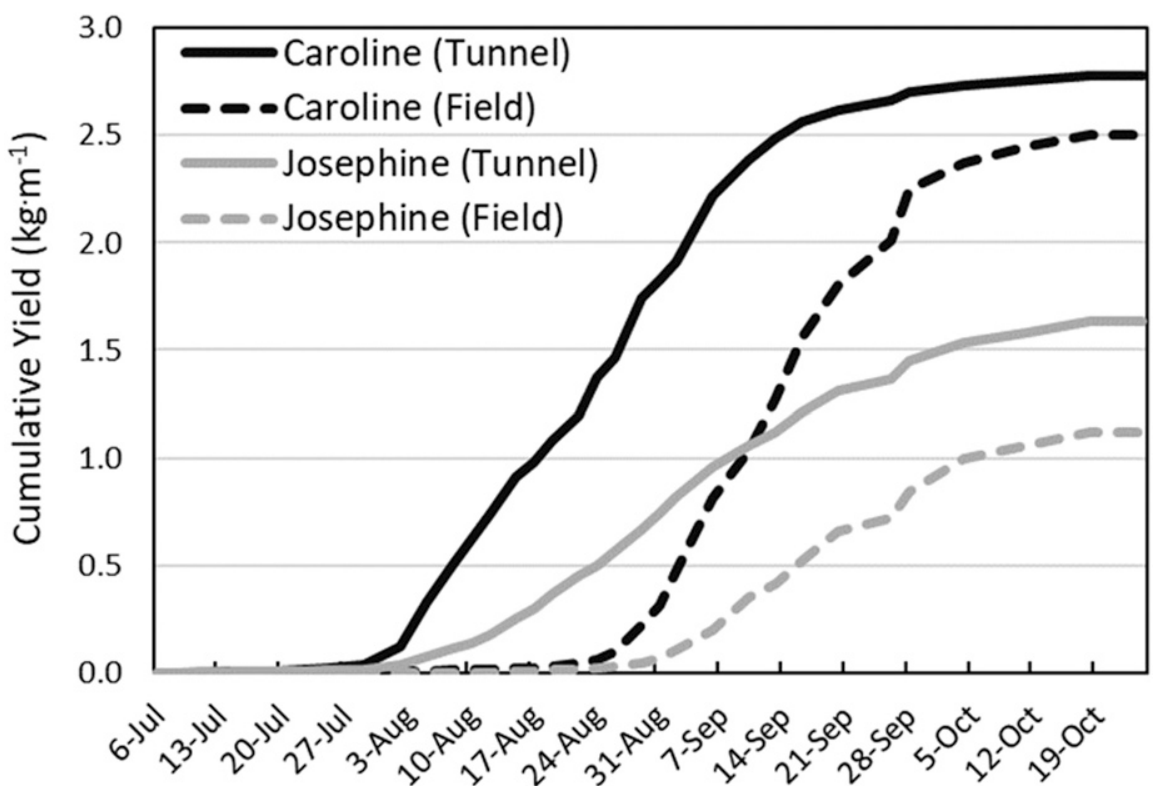

Fig. 1. Cumulative yield of 'Caroline' and 'Josephine' raspberry in a two-season tunnel and in the field during the 2016 season. Values are means of two replicate 12.8-m-long plots.

Table 2. Effects of a two-season high tunnel on the harvest season of two primocane-fruiting cultivars. Harvest start was calculated based on regression of the cumulative yield using the projected $\mathrm{X}$-axis intercept.

\begin{tabular}{|c|c|c|c|c|c|c|c|}
\hline \multirow[b]{2}{*}{$\mathrm{Yr}$} & \multirow[b]{2}{*}{ Cultivar } & \multicolumn{3}{|c|}{ Harvest start } & \multicolumn{3}{|c|}{ Season midpoint } \\
\hline & & Tunnel & Field & dif. & Tunnel & Field & dif. \\
\hline \multirow[t]{2}{*}{2016} & Caroline & 30 July & 25 Aug. & 26 & 25 Aug. & 14 Sept. & $\overline{20}$ \\
\hline & Josephine & 6 Aug. & 28 Aug. & 22 & 3 Sept. & 18 Sept. & 15 \\
\hline \multirow[t]{2}{*}{2017} & Caroline & 30 July & 25 Aug. & 26 & 22 Aug. & 12 Sept. & 21 \\
\hline & Josephine & 8 Aug. & 26 Aug. & 18 & 28 Aug. & 15 Sept. & 18 \\
\hline \multicolumn{8}{|c|}{ Analysis of variance $P$ values } \\
\hline & Tunnel & & 0.002 & & & 0.001 & \\
\hline & Cultivar & & 0.12 & & & 0.036 & \\
\hline & Tunnel $\times$ cultivar & & 0.33 & & & 0.26 & \\
\hline & Year & & 0.26 & & & 0.028 & \\
\hline
\end{tabular}

Table 3. Effects of a two-season tunnel on marketable fruit (\%) for two cultivars over two seasons. Fruit was rated unmarketable due to a number of causes such as sunburn, crumbly fruit, and insect or disease damage.

\begin{tabular}{|c|c|c|c|c|}
\hline \multirow[b]{2}{*}{$\mathrm{Yr}$} & \multirow[b]{2}{*}{ Cultivar } & \multicolumn{3}{|c|}{ Marketable (\%) } \\
\hline & & Tunnel & Field & $\overline{\text { dif. }}$ \\
\hline \multirow[t]{2}{*}{$\overline{2016}$} & Caroline & 92.4 & 81.8 & $\overline{10.6}$ \\
\hline & Josephine & 94.7 & 85.8 & 8.9 \\
\hline \multirow[t]{2}{*}{2017} & Caroline & 76.6 & 75.2 & 1.4 \\
\hline & Josephine & 85.4 & 78.1 & 7.2 \\
\hline \multicolumn{5}{|c|}{ Factorial analysis of variance $P$ values } \\
\hline & Tunnel & & 0.02 & \\
\hline & Cultivar & & 0.06 & \\
\hline & Tunnel $\times$ cultivar & & 0.55 & \\
\hline & Year & & 0.0003 & \\
\hline & Tunnel $\times$ year & & 0.03 & \\
\hline & Cultivar $\times$ year & & 0.18 & \\
\hline & Tunnel $\times$ cultivar $\times$ year & & 0.089 & \\
\hline
\end{tabular}

commercial application of shade cloth is becoming more common to reduce sunburn issues associated with berry and vegetable production in the Intermountain West. The lower marketability in 2017 compared with that in 2016 was caused by a combination of factors. Fruit of 'Caroline' tended to be soft and crumbly, which was likely due to inadvertently high $\mathrm{N}$ fertilizer applications rates. Insect activity (leaf hoppers early in strained by the first fall freeze (Black et al., 2013). This suggested that by advancing the production season earlier, more of the total fruiting potential in a primocane-only crop would be realized, particularly with later fruiting cultivars such as Josephine. The 'Josephine' plots in tunnels had higher average yields than the corresponding field plots (46\% and 35\% increases in 2015 and 2016, respectively). However, these differences were not statistically significant, possibly due to the low replication number. Under Michigan conditions, Hanson et al. (2011) reported consistently higher yields in high tunnels for three seasons than in corresponding field plots, but they did not perform a statistical comparison of the tunnel effect because of the low replication number.

Fruit size was significantly greater for 'Josephine' than for 'Caroline'. However, there was also a significant tunnel $\times$ cultivar interaction (Table 4). In the case of 'Caroline', fruit size was larger in the field than in the tunnel. However, the fruit size of 'Josephine' was larger in the tunnel during 2016, but it did not differ between the field and tunnel in 2017. This lack of a consistent tunnel effect on fruit size contradicted the findings of Weber (2018), who reported that fruit was consistently larger under tunnel conditions. Hanson et al. (2011) reported larger fruit size in tunnels than in the field, but only for select cultivars. However, both of these studies used three-season tunnels, which presented very different fruit ripening conditions than did the system of plastic cover in the spring and shade in the summer.

The primary management objective of high tunnels is temperature management, although humidity and light conditions are also altered. The relationship between temperature and primocane crop development has been explored in several published studies. Lockshin and Elfving (1981) found that under controlled environment conditions, 'Heritage' raspberry flowered earlier and produced more flowers with a $29 / 24{ }^{\circ} \mathrm{C}$ day/night temperature cycle compared with $25 / 20^{\circ} \mathrm{C}$. Hoover et al. (1989) monitored temperatures and crop development of two cultivars of PF raspberry in five locations and found a strong relationship between temperature and primocane height, but there was no strong correlation between heat unit accumulation and harvest season. Privé et al. (1993b) followed three cultivars over the course of two seasons and six locations and found that the date of the first harvest was strongly correlated with soil temperature and water availability, but only weakly correlated with air temperature (based on a corn heat unit model).

It is important to note that the cultivars used in this study were initially selected for late fruiting studies, but not early primocane cropping, as was the objective in this study. Under field conditions in Northern Utah, 'Caroline' is considered an early midseason cultivar, whereas 'Josephine' is typically too late to be commercially viable for field production (Black et al., 2013). Under Michigan conditions, these cultivars are considered 
Table 4. Effects of cultivar and tunnels on total season yield and fruit size. Fruit size is a weighted average based on a subsample fruit weight measured at each harvest date and the fraction of the total season yields harvested on that date.

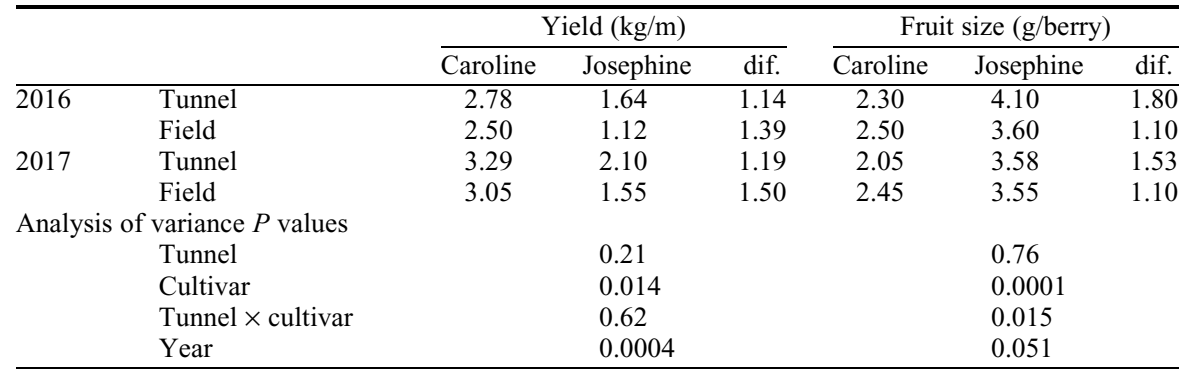

midseason to late midseason cultivars (Hanson et al., 2018). Additional research should focus on using this system with earlier cultivars such as Polka or Autumn Britten.

\section{Conclusion}

Some small-acreage growers in the highelevation valleys of the Intermountain West are struggling to achieve consistent raspberry production to supply high-value local markets. Productivity of floricane-fruiting cultivars is limited by winter injury, and the growing season is not consistently long enough for field production of a primocane crop. Using simple, low-cost, two-season tunnels to modify early spring growth might provide an economically viable method of alleviating these seasonal risks. However, a better understanding of the relationship between temperature modification and crop development would provide better tunnel management recommendations. An economic evaluation of the costs and benefits of spring protection for early fall production is also necessary.

\section{Literature Cited}

Barlow, J.C. 1963. The effects of light, wax, and temperature treatments before and after rest on the growth of Latham raspberry plants. Utah State Univ., Logan, M.S. Thesis.

Black, B.L., T. Lindstrom, R. Heflebower, B Hunter, S. Olsen, and D.G. Alston. 2013. Adaptability of primocane-fruiting raspberry cultivars to a high-elevation arid climate. J. Amer. Pomol. Soc. 67:47-56.
Black, B.L., T. Lindstrom, B. Hunter, S. Olsen, R. Heflebower, D.G. Alston, and T. Maughan. 2015. Adaptability of floricane-fruiting raspberry cultivars to a high-elevation, arid climate. J. Amer. Pomol. Soc. 69:74-83.

Carew, J.G., K. Mahmood, J. Darby, P. Hadley, and N.H. Battey. 2003. The effect of temperature, photosynthetic photon flux density, and photoperiod on the vegetative growth and flowering of 'Autumn Bliss' raspberry. HortScience 128:291-296

Demchak, K. 2009. Small fruit production in high tunnels. HortTechnology 19:44-49.

Demchak, K., W.J. Lamont, and M.D. Orzolek. 2003. High tunnel berry production. High Tunnel Production Manual. University Park, Pennsylvania Univ. p. 119-126.

Handley, D. and C. Weber. 2008. Plant selection, p. 17-27. In: L. Bushway, M. Pritts, and D. Handley (eds.). Raspberry and blackberry production guide for the Northeast, Midwest, and Eastern Canada. Natural Resource, Agriculture, and Engineering Service, Ithaca, NY.

Hanson, E., B. Crain, and D. Brown-Rytlewski. 2018. Primocane-Fruiting Red Raspberry Cultivar Evaluation in High Tunnels. J. Amer. Pomol. Soc. 72:122-127.

Hanson, E., M. Von Weihe, A.C. Schilder, A.M Chanon, and J.C. Scheerens. 2011. High tunnel and open field production of floricane - and primocane-fruiting raspberry cultivars. HortTechnology 24:412-418.

Hoover, E., J. Luby, D. Bedford, M. Pritts, E. Hanson, A. Dale, and H. Daubeny. 1989. Temperature influence on harvest date and cane development of primocane-fruiting red raspberries. Acta Hort. 262:297-304.

Lockshin, L.S. and D.C. Elfving. 1981. Flowering response of 'Heritage' red raspberry to temperature and nitrogen. HortScience 16:527528.
Maughan, T. and B. Black. 2018. Late-season raspberry production in high tunnels: Varieties. USU Extension. Paper 1868. <https://digitalcommons. usu.edu/extension_curall/1868>.

Maughan, T., D. Rowley, B. Black, and D. Drost. 2014. Constructing a low-cost high tunnel for tall crops ( $14.5^{\prime}$ wide by $10^{\prime}$ tall). USU Extension. Paper 1668. <https://digitalcommons.usu. edu/extension_curall/1668/>.

Moller, A.L. and R.R. Gillies. 2008. Utah Climate. 2nd ed. Utah Climate Center, Utah State Univ. $<\mathrm{http}: / /$ climate.usu.edu $>$.

Nonnecke, G.R. and J.J. Luby. 1992. Raspberry cultivars and production in the Midwest. Fruit Var. J. 46:207-212.

Pritts, M. 2006. High tunnels for late fall raspberries. New York Fruit Quarterly 14:1-4.

Pritts, M., E. Hanson, J. Fiola, and M.J. Kelly. 1992. Rowcovers accelerate fruiting and increase productivity in primocane-fruiting red raspberries. HortTechnology 2:46-51.

Pritts, M., L. McDermott, K. Demchak, E. Hanson, C. Weber, A. Both, G. Loeb, and C. Heidenreich. 2017. High tunnel raspberries and blackberries. Cornell Cooperative Extension. <http://www.hort. cornell.edu/fruit/pdfs/high-tunnel-brambles.pdfs.

Privé, J., J.A. Sullivan, J.T.A. Proctor, and O.B. Allen. 1993a. Performance of three primocanefruiting red raspberry cultivars in Ontario and Quebec. J. Amer. Soc. Hort. Sci. 118:388-392.

Privé, J., J.A. Sullivan, J.T.A. Proctor, and O.B. Allen. 1993b. Climate influences vegetative and reproductive components of primocanefruiting red raspberry cultivars. J. Amer. Soc. Hort. Sci. 118:393-399.

Rowley, D.R. 2010. Season extension of strawberry and raspberry production using high tunnels. Utah State University, Logan, M.S. Thesis. $<$ https://digitalcommons.usu.edu/etd/716>.

Strik, B.C., J.R. Clark, C.E. Finn, and G. Buller 2012. Management of primocane-fruiting blackberry: Impacts on yield, fruiting season, and cane architecture. HortScience 47:593598.

Swartz, H.J., J.A. Fiola, H.D. Stiles, and B.A. Smith. 1998. Raspberry plant named 'Caroline'. Patent 10412 USA.

Swartz, H.J., J.A. Fiola, H.D. Stiles, and B.A. Smith. 2001. Raspberry plant named 'Josephine'. Patent 12173 USA.

Weber, C.A. 2018. High Tunnel Performance of Seven Primocane Red Raspberry Cultivars in Western NY. J. Amer. Pomol. Soc. 72:195201.

Yao, S. and C.J. Rosen. 2011. Primocane-fruiting raspberry production in high tunnels in a cold region of the upper Midwestern United States. HortTechology 21:429-434. 